\title{
The emergence of science communication in Aotearoa New Zealand
}

\section{Jean Fleming and Jeremy Star}

\begin{abstract}
The history of science communication in Aotearoa New Zealand starts with the stories told by the indigenous Mãori people and has often been rooted in large, controversial environmental or technological issues. Although science communication in New Zealand began with a culture of wise men informing an uneducated public, by the 1990s it had begun to explore ideas of public outreach and engagement. Driven in part by the country's landscape and unique wildlife, media such as film documentary have risen to take centre stage in public engagement with science. Public radio also features in discussion of scientific issues. New centres for the training of science communicators have emerged and there is governmental and public support for science communication in New Zealand, as demonstrated by the number of awards and funding opportunities offered annually, for those who achieve. However a more critical and strategic approach to science communication in the future is needed if New Zealand wants a more science-literate public, and a more public-literate science community.
\end{abstract}

Keywords

History of public communication of science

Introduction

Aotearoa ${ }^{1} \mathrm{New}$ Zealand is a relatively isolated country with a population of over 4.5 million people. Its geography has ensured a culture of exploration, discovery and communication. Science communication started as an oral tradition with the indigenous people and has developed through community movements on environmental issues, to institutional communication mechanisms and public outreach. However development of New Zealand's science communication appears to parallel that of other "Western" countries, such as Australia, the United States or Great Britain, rather than arising from the Māori culture itself. Science communication has now become a career and an academic research field, especially over the last decade in New Zealand, in response to a need for a skilled workforce with increased science literacy. This paper traces the emergence of science communication in New Zealand, from the public lecture to participatory science. A timeline of the major events is shown in Table 1.

\footnotetext{
${ }^{1}$ Aotearoa is the Māori name for New Zealand.
} 
Table 1: Timeline of the history of science, science communication and public engagement with science in New Zealand.

\begin{tabular}{|c|c|}
\hline Year & New Zealand Timeline \\
\hline Before 1700 & Mātauranga Māori — indigenous knowledge of biodiversity, ecology and geography of Aoteoroa, New Zealand \\
\hline 1769 & $\begin{array}{l}\text { Captain James Cook's voyages; Endeavour 1769-70 (Joseph Banks' collections; Kew Gardens); Resolution 1773- } \\
\text { 74; Transit of Venus observed by Cook } 1769\end{array}$ \\
\hline 1840 & The Treaty of Waitangi between Māori and non-Māori \\
\hline 1841 & $\begin{array}{l}\text { Early institutions: The NZ Literary and Scientific Institution of Nelson formed 1841. The Philosophical Institute } \\
\text { of Canterbury (Julius Haast) } 30 \text { August } 1862 \text {. Auckland Philosophical Society formed 1867, became Auckland } \\
\text { Institute in 1868. The New Zealand Society formed } 2 \text { July 1851. The Wellington, Auckland, and Canterbury } \\
\text { bodies, along with the Westland Naturalists' and Acclimatisation Society, constituted the societies incorporated } \\
\text { in the New Zealand Institute (for the advancement of sciences and the arts), formed through the NZ Institute } \\
\text { Act of 1867, the Otago Institute being added in } 1869 \text {. }\end{array}$ \\
\hline 1865 & $\begin{array}{l}\text { Museums: Colonial Museum, Wellington 1865; Auckland Museum (established around 1864-5) moves to Pro- } \\
\text { vincial Colonial Building 1867; Canterbury Museum, Christchurch; Otago Museum Dunedin 1868; }\end{array}$ \\
\hline 1865-1925 & $\begin{array}{l}\text { Industrial exhibitions: Between } 1865 \text { and 1925, at least } 22 \text { industrial exhibitions took place in New Zealand. The } \\
\text { first in Dunedin in } 1865 \text { led to the establishment of Otago Museum (1868) and New Zealand's first Art \& Design } \\
\text { school (1870). }\end{array}$ \\
\hline 1868 & Transactions of the NZ Institute, later RSNZ, from 1868; New Zealand Journal of Science 1870s-1885 \\
\hline 1869 & $\begin{array}{l}\text { Universities: University of Otago founded in } 1869 \text { and Canterbury College (now the University of Canterbury) } \\
\text { in } 1873\end{array}$ \\
\hline 1891 & $\begin{array}{l}\text { The RSNZ collaborated with ANZAAS, hosting occasional congresses since 1891. After } 1933 \text { the RSNZ and the } \\
\text { NZ Institute nominated delegates to Pan Pacific Science Congresses (later Pacific Science Conferences), set up in } \\
\text { Honolulu in 1920. }\end{array}$ \\
\hline 1892 & $\begin{array}{l}\text { Australian Association for the Advancement of Science, founded in } 1891 \text {, held occasional congresses in New } \\
\text { Zealand, the first occasion being the } 3^{\text {rd }} \text { Congress, held in Christchurch in } 1891 \text {. }\end{array}$ \\
\hline 1919 & $\begin{array}{l}\text { The NZ Institute established the first Science Congress, in Christchurch, } 4-8 \text { Feb 1919. Others followed at inter- } \\
\text { vals of a few years, the second being held at Palmerston North on 25-29 Jan } 1921 .\end{array}$ \\
\hline 1923 & $\begin{array}{l}\text { Native Bird Protection Society was established at a public meeting in March 1923, by Captain Val Sanderson. It } \\
\text { later became the Royal Forest and Bird Protection Society, known more simply as Forest \& Bird. }\end{array}$ \\
\hline 1926 & The New Zealand Government established a new Department of Scientific and Industrial Research (DSIR). \\
\hline 1933 & The Royal Society of NZ was formed from the NZ Institute and the Royal Title was approved on 25 May 1933. \\
\hline 1942 & $\begin{array}{l}\text { NZ Association of Scientific Workers (later the NZ Association of Scientists) formed. 'The scientist — Today's } \\
\text { forgotten man' was the title of the editorial in the first issue of New Zealand Science Review, published in December } \\
1942 \text {. }\end{array}$ \\
\hline 1951 & $\begin{array}{l}\text { NZAS Research Medal established, recognising "outstanding fundamental or applied research ... published by } \\
\text { a scientist under the age of } 40 \text { during the year of the award or the preceding three calendar years'. }\end{array}$ \\
\hline 1957 & NZ Broadcasting service Science Report radio show was \\
\hline 1960 & $\begin{array}{l}\text { Auckland Science Fairs (competitions for primary a } \\
\text { lington Science Fairs in 1964. National Science Fairs s }\end{array}$ \\
\hline 1964 & Formation of MOTAT (Museum of Transport \& Technology), Western Springs, Auckland \\
\hline 1959-72 & $\begin{array}{l}\text { The Save Manapouri Campaign was an environmental campaign waged between } 1959 \text { and } 1972 \text { in New Zealand } \\
\text { to prevent the raising of the levels of lakes Manapouri and Te Anau as part of the construction of the Manapouri } \\
\text { Power Project. }\end{array}$ \\
\hline 1969 & $\begin{array}{l}\text { NZAS establishes Service to Science Medal, later to be called the Marsden Medal, recognising a 'lifetime of } \\
\text { outstanding service to the cause or profession of science'. }\end{array}$ \\
\hline 1974 & $\begin{array}{l}\text { Journalist Neil Harraway and cameraman Robert Brown made a television documentary on takahe, signalling } \\
\text { the emergence of natural history filmmaking in Dunedin. }\end{array}$ \\
\hline 1976 & $\begin{array}{l}\text { For DSIR's } 50^{\text {th }} \text { Jubilee in 1976, Geoff Gregory scripted a film, Research 50, which was available for schools and } \\
\text { public showing. It was followed by one on Crop Research in DSIR, and in 1986, in video because of changing } \\
\text { technology, one on Volcanoes in New Zealand, 'Ruamoko's Heritage'. }\end{array}$ \\
\hline 1977 & $\begin{array}{l}\text { Formation of Natural History Unit by Hal Weston, the manager of New Zealand Television One, Dunedin. The } \\
\text { Unit, later led by Michael Stedman, evolved into Natural History New Zealand (now NHNZ). }\end{array}$ \\
\hline 1970s-80s & $\begin{array}{l}\text { The rise of the conservation movement (including Forest \& Bird and ECO in1972) in New Zealand. Don Merton } \\
(1939 \text { - 2011), conservationist: best known for saving the black robin from extinction. He also discovered the lek } \\
\text { breeding system of the kakapo and was pivotal in communicating conservation to the ordinary person. }\end{array}$ \\
\hline 1980s & $\begin{array}{l}\text { formation Officers established for the DSIR to organise scientific community information and educational ma- } \\
\text { rial. These positions continued in some of the Crown Research Institutes when they were formed in the 1990s. }\end{array}$ \\
\hline
\end{tabular}


Table 1: Continued from the previous page.

\begin{tabular}{|c|c|}
\hline Year & New Zealand Timeline \\
\hline 1980 & $\begin{array}{l}\text { Science Information Division of DSIR started a series of popular science information leaflets ('DSIR Extension } \\
\text { Information'), called the Alpha series. }\end{array}$ \\
\hline 1980 & $\begin{array}{l}\text { NZAS established a Science Journalism Award in 1980, but discontinued it in 2002, the last recipient (in 2001) } \\
\text { being Kim Hill, the radio journalist. }\end{array}$ \\
\hline 1980 & $\begin{array}{l}\text { Prof George Hines at Massey University started a Communication option in the Diploma in Business and Admin- } \\
\text { istration, which included science communication. Frank Sligo, Associate Professor of Communication, Journal- } \\
\text { ism and Marketing, ran the Communication courses. }\end{array}$ \\
\hline 1984 & $\begin{array}{l}\text { Hui Whakaoranga (public health gatherings for Māori) established by Dr Pat Ngata, Eru Pomare, Lorna Dyall, } \\
\text { George Salmond and Mason Durie. These hui were described as "the most important Māori health initiative } \\
\text { since the days of Apirana Ngata and Peter Buck". }\end{array}$ \\
\hline 1986 & $\begin{array}{l}\text { Formation of the NZ Association for Women In the Sciences. 1993: Women's Suffrage Centennial Science Con- } \\
\text { ference. Subsequent AWIS conferences every three years. }\end{array}$ \\
\hline 1987 & $\begin{array}{l}\text { The Association of Scientific and Technical Communicators (NZ) Inc established in } 1987 \text { and officially incorpor- } \\
\text { ated in 1988. It ran quarterly meetings with speakers, produced a newsletter, and held the first national science } \\
\text { communicators' conference. It went into recess in 1996. }\end{array}$ \\
\hline 1990 & Science Communicator's Award (for scientists, not journalists) established by the NZ Association of Scientists. \\
\hline 1990 & Hands-on Science secondary school science summer camp, established at the University of Otago \\
\hline 1990 & $\begin{array}{l}\text { Science Monthly Magazine - Vicki Hyde ONZM founded and was Managing Editor of New Zealand Science } \\
\text { Monthly magazine, published for the full decade from } 1990 \text { to } 2000 .\end{array}$ \\
\hline 1991 & Discovery World opens at the Otago Museum, Dunedin \\
\hline 1992 & Science Alive! science centre opens in Christchurch \\
\hline 1992 & $\begin{array}{l}\text { Museum of New Zealand Te Papa Tongarewa was established by the Museum of New Zealand Te Papa } \\
\text { Tongarewa Act } 1992 \text {. The official opening took place on } 14 \text { February 1998. The museum's principles incor- } \\
\text { porate the concepts of unified collections; the narratives of culture and place; the idea of forum; the bicultural } \\
\text { partnership; and an emphasis on diversity and multidisciplinary collaboration. }\end{array}$ \\
\hline 1992 & $\begin{array}{l}\text { On July 1, 1992, } 10 \text { Crown research institutes were formed - the most radical reorganisation of government } \\
\text { science in New Zealand's history. The aim was to group scientists into institutes with separate research aims } \\
\text { and subject areas. They also provided for commercial funding of research. At the same time Science New } \\
\text { Zealand was established (http://www.sciencenewzealand.org/About-Science-New-Zealand/Who-we-are). It } \\
\text { represents the (now) seven Crown Research Institutes. Its purpose is to foster appreciation of the value of science } \\
\text { and technology in creating economic, environmental and social wealth for New Zealand. }\end{array}$ \\
\hline 1994 & $\begin{array}{l}\text { The Association of Scientific and Technical Communicators (NZ) Inc. ran a 2-day Conference, 'Communicating } \\
\text { Science, Communicating Technology' opened by the Minister of Science, Hon Simon Upton, the Proceedings of } \\
\text { which were published. }\end{array}$ \\
\hline 1998 & First International Science Festival in Dunedin. Now a well-established biannual event. \\
\hline 1999 & Foundation for Research, Science \& Technology Science Communicator's Awards established \\
\hline $2000-2001$ & $\begin{array}{l}\text { New Zealand Royal Commission on Genetic Modification concluded stakeholder participation needed for } \\
\text { decision-making on "wicked" problems. }\end{array}$ \\
\hline 2001 & $\begin{array}{l}\text { EOS Ecology established in Christchurch with particular strengths in urban ecology, infrastructure, waterway } \\
\text { restoration, invertebrate identification and science communication. }\end{array}$ \\
\hline 2001 & First Science Communicators' Conference run by the RSNZ in Wellington. \\
\hline 2002 & $\begin{array}{l}\text { NZAS Science Communicator's Award established, made to a practising scientist for excel- } \\
\text { lence in communicating science to the general public in any area of science or technology. } \\
\text { http://www.scientists.org.nz/awards/communicator-award }\end{array}$ \\
\hline 2004 & $\begin{array}{l}\text { Formation of the Science Communicators' Association of NZ (SCANZ) by Peter Burke. Annual conferences } \\
\text { thereafter (http:/ / www.scanz.co.nz). }\end{array}$ \\
\hline 2005 & $\begin{array}{l}\text { Formation of the Biotech Learning Hub, Hamilton, led by Alister Jones, Waikato University, providing biotech- } \\
\text { nology information for primary and secondary schools (http:/ / www.biotechlearn.org.nz). }\end{array}$ \\
\hline 2006 & $\begin{array}{l}\text { LENScience established in the Sir John Logan Campbell classroom at the Liggins Institute, Auckland. } \\
\text { LENScience's programmes provide opportunities for school students and teachers to learn about the latest ad- } \\
\text { vances in the life sciences. }\end{array}$ \\
\hline 2007 & $\begin{array}{l}\text { Launch of the Science Learning Hub, Hamilton (http:/ /www.sciencelearn.org.nz), providing science resources } \\
\text { for schools. }\end{array}$ \\
\hline $2007-2012$ & Royal Society of New Zealand Manhire Prize for Creative Science Writing \\
\hline
\end{tabular}


Table 1: Continued from the previous page.

\begin{tabular}{|l|l|}
\hline Year & New Zealand Timeline \\
\hline $2005-2011$ & $\begin{array}{l}\text { Interviews with Professor Sir Paul Callaghan and radio journalist Kim Hill, on Radio NZ National on a wide } \\
\text { range of science topics and on Sir Paul's battle with cancer (http:/ / www.radionz.co.nz/collections / sirpaul). A } \\
\text { summary of these conversations, As Far as We Know: Conversations about Science, Life and the Universe, appeared } \\
\text { in 2007. }\end{array}$ \\
\hline 2007 & $\begin{array}{l}\text { University of Otago's Science Wananga established: Māori scientists and postgraduate students visiting Māori } \\
\text { communities and talking about relevant local science issues. }\end{array}$ \\
\hline 2008 & $\begin{array}{l}\text { Formation of the University of Otago Centre for Science Communication. Arose out of NHNZ collaboration with } \\
\text { University of Otago's Zoology Dept. in 2001. }\end{array}$ \\
\hline 2008 & $\begin{array}{l}\text { Weekly interviews by Bryan Crump on Radio NZ National Nights programme with a wide range of scientists, } \\
\text { on topics from Extreme Weather to Body Parts. }\end{array}$ \\
\hline 2008 & $\begin{array}{l}\text { NZ Science Media Centre established, funded by the Ministry of Research, Science\& Technology and run through } \\
\text { the RSNZ }\end{array}$ \\
\hline 2009 & $\begin{array}{l}\text { First RSNZ Science Book Prize (biannual), won by Rebecca Priestley for The Awa Book of New Zealand Science. } \\
\text { versity of Otago, Dunedin }\end{array}$ \\
\hline 2011 & $\begin{array}{l}\text { The establishment of the NZ Prime Minister's Science Media Communication Prize } \\
\text { PCST-SCANZ Conference in Christchurch, on Disasters, first New Zealand international science communication } \\
\text { conference. }\end{array}$ \\
\hline 2009 & Launch of the NZ Science Challenges: the first government programme to promote science communication \\
\hline 2013 & $\begin{array}{l}\text { "A Nation of Curious Minds". The launch of the Science in Society Project, by the Ministry of Business, Innova- } \\
\text { tion and Employment (includes research, science and technology). }\end{array}$ \\
\hline 2014 & $\begin{array}{l}\text { NZAS changes the name of the Research Medal to the Beatrice Hill Tinsley Medal, in honour of New Zealand's } \\
\text { famous cosmologist. }\end{array}$ \\
\hline 2016 &
\end{tabular}

Mātauranga Māori The first people arrived on New Zealand's shores less than a thousand years ago [Higham, Anderson and Jacomb, 1999; Wilmshurstl and Higham, 2004; Perry, Wilmshurst and McGlone, 2014], making New Zealand the last major land mass on the planet to be settled [Roberts, 1991]. Māori, the indigenous people of Aotearoa New Zealand, have a deep knowledge of the world around them, from astronomy to agriculture, which is referred to as Mātauranga Māori or Mātauranga Putaiao. Māori's ability to navigate the Pacific from Polynesia to New Zealand and Rapanui (Easter Island), using the stars, the currents and the wildlife to guide them, is documented [Adds, 2012] and has been verified recently with the Waka Tapu expeditions (http://wwww.wakatapu.Māori.nz/index.html). Māori adapted their agriculture to the temporal climate and related the yearly star cycle to seasonal activities such as the planting and harvesting of crops [Best, 1930; Best, 1931]. Mātauranga Māori is therefore an important cultural context of science communication in New Zealand [Broughton and McBreen, 2015]. However the development of science communication in New Zealand has followed the path of English-speaking nations, such as Australia and the United Kingdom, rather than arising from the Māori culture.

Science in colonial New Zealand
Captain James Cook first visited New Zealand in 1769, having observed the transit of Venus in Tahiti. On this and subsequent visits Cook's team made astronomical observations and collected plants and animals [Murray and Howse, 1997; Priestley, 2010; Donald, 2012]. Geological and biological discoveries were well reported by the early scientific and philosophical institutes and societies, set up in the main population centres of Auckland, Dunedin, Nelson, Christchurch and Wellington [Fleming, 1987]. Mātauranga Māori was ignored or regarded negatively as 
superstition or myth, in the context of a colonial government interested in new knowledge and resources [Broughton and McBreen, 2015].

Early communication of science in the $19^{\text {th }}$ century was primarily peer-to-peer, with occasional public lectures and congresses. Scientists developed formal groupings, with the establishment of the New Zealand Institute in 1867 (renamed the Royal Society of New Zealand [RSNZ] in 1933). The New Zealand Institute, formed gradually from consolidated regional Institutes, established a society to connect scientists and support research in the new country [Fleming, 1987] and published the first scientific papers (Transactions, 1868).

The Australasian Association for the Advancement of Science, founded in 1891 to promote science, held occasional public science congresses in New Zealand, the first occasion being the $3^{\text {rd }}$ Congress, held in Christchurch in 1891 [Hector, 1891]. The Institute established the first Science Congress, held again in Christchurch, 4-8 Feb 1919 [Anon., 1919]. Others followed at intervals of a few years, the second being held at Palmerston North on 25-29 Jan 1921 [Anon., 1921].

Museums were established throughout the country in the mid nineteenth century, as geologists, naturalists and botanists started collecting specimens of New Zealand flora and fauna [Gill, 2006; Gill, 2010; Nelson, Dalen and Neill, 2013; Robinson, 2012]. Auckland Museum was established around 1864-5 and Colonial Museum was opened in the capital city Wellington in 1865. Both Canterbury Museum in Christchurch and Otago Museum in Dunedin opened in 1868 [Fleming, 1987].

1900-1970: New Zealand government science
In the mid 1920s, the newly elected Reform Party government proposed a state scientific organisation, applying science to industry. The Department of Scientific and Industrial Research (DSIR) was subsequently formed in 1926 [Atkinson, 1976]. In 1918, the Dominion Museum started publishing NZ Journal of Science and Technology, but as it was struggling financially, attempts were made to popularise it, without success. In 1927, to bear the costs while upholding scientific standards, the DSIR took it over [Atkinson, 1976]. With the expansion of scientific manpower in the late 1950s, the number and diversity of submitted papers forced a split into NZ Journal of Science, New Zealand Journal of Agricultural Research, and New Zealand Journal of Geology and Geophysics [Callaghan, 1976]. In the first two-thirds of the twentieth century, scientific research was seen as elite and secret. The Official Secrets Act and the State Services Act all limit government scientists' freedom of speech [Hendy, 2016].

The New Zealand Association of Scientific Workers, later the NZ Association of Scientists (NZAS) was formed in 1942. The objectives of the latter organisation were "to secure the wider application of science and the scientific method for the welfare of society and to promote the interests of scientific workers", thus establishing this group as the first science communication organization in New Zealand [Gregory, 2013]. The NZAS published The New Zealand Science Review, aimed at a broader audience, the year they were founded [Gregory, 2013]. This group also set up the first awards for science communication (see below). The mid twentieth century therefore saw the beginning of science communication in New Zealand, primarily involving experts informing an assumed uninformed public [Ahteensuu, 2011; McNeil, 2013]. 
1970-1990

Development of

the "clean, green

New Zealand"

brand
Historically, New Zealanders' engagement with science was often connected with large, controversial environmental issues, such as proposals for nuclear power or the raising of lakes for hydroelectricity. This coincided with increased political awareness of environmental issues, the formation of the New Zealand Values Party (a forerunner to the Greens Party; [Vowles, 1995] ), the election of a New Zealand Labour Party government, led by Norman Kirk, and passing of the Equal Pay Act, all in 1972 [Hayward, 2014]. In the Save Manapouri Campaign, which ran between 1959 and 1972, New Zealanders mobilised to prevent the raising of the levels of lakes Manapouri and Te Anau as part of the construction of the Manapouri Power Project [Mark and Johnson, 1985; Mark, 2001]. This movement, which commenced in 1959, later came to manifest the international awareness of the environment that came with the prosperity of the 1960s.

New Zealanders stood together again in 1978, this time to demonstrate against the clearing of native forest, during protests over the clear felling of Pureora Forest, home to the endangered native bird, the kokako. These protests were ultimately successful, leading to cessation of widespread logging in Pureora and elsewhere in New Zealand [Wright, 1980; Downes, 2000; Beveridge et al., 2009].

Similar mobilisation of a strong environmental movement in New Zealand was seen in the development of the anti-nuclear campaign. In the 1960s, after France started testing nuclear weapons in the Pacific, lobbying by the Public Service Association led the Department of Health to begin issuing quarterly reports on the levels and health impacts of radioactive fallout in New Zealand. [Priestley, 2006, p. 140]. Protests against visits from nuclear-powered ships began in the 1970s, under the Kirk Labour Government [Brooking, 2004], as did movement against the introduction of nuclear power for electricity generation in New Zealand [Reitzig, 2005; Dewes, 2012]. The Royal Commission on Nuclear Power Generation in New Zealand, set up in 1976, reported in 1978 [McCarthy, 1978], advising against the introduction of nuclear power to New Zealand, not for health reasons, but because cheaper sources of power had been found.

New Zealand's landscapes and unusual animals have also been a catalyst for the development of the wildlife documentary [Heron, 2004]. It could be argued that the development of wildlife filmmaking led to the first public awareness of science communication in this country. In 1974, Dunedin-based journalist Neil Harraway and cameraman Robert Brown made a television documentary about an endangered native bird called the takahe. Their work led to the establishment of New Zealand Television One's Natural History Unit in 1977. Led by Michael Stedman, the unit gained international recognition for its documentaries on wildlife and natural history (http:/ / www.nhnz.tv/home). It was sold to Twentieth Century Fox in 1997 and renamed Natural History New Zealand. Driven by financial necessity, the outlook of NHNZ (as it is now known) and the content it produces has become increasingly global. It remains based in Dunedin, however, and continues to produce New Zealand wildlife documentaries, alongside international science-focused, and non-science focused programmes [Star, 2015]. 
1990-2000:

control of scientists and scientific information

In 1990, a general election saw the replacement of the Labour Government with a central right National Government, led by Jim Bolger. In New Zealand, as elsewhere in the world, there was increased public unease at the arrival of technologies such as genetic engineering and assisted reproductive technology [Hodder, 2010] and a call for scientists to have more social responsibility [Gregory, 2014]. The new government moved fast to dismantle DSIR and restructure all government scientific departments into ten new Crown Research Institutes (CRIs), administered by a new Ministry of Research, Science \& Technology and funded largely through a separate Foundation for Research, Science \& Technology [Gregory, 2014]. The aim of this restructuring was to focus New Zealand research science on the needs and end uses of commercial science and technology and to establish competitive funding for research. This restructuring led to the development of media and public relations offices in CRIs and made it harder for government scientists to communicate freely about their research [Ashwell, 2014].

Māori studies were taught at Auckland University from 1952 and at Victoria University of Wellington from 1967 [Mead, 1983], but there was little to no discussion of Mātauranga Māori in science until the 2000s [Jenkins and Pihama, 2001; Hirini, 2006; Henwood, 2007; Lyver et al., 2008; Crawford, 2009; Moller, 2009; Moller et al., 2009].

New Zealand women in science
In the 1960s, New Zealand science, both in DSIR and in the universities, was dominated by male academics, with few women reaching the highest positions [Brooks, 1997; Baker, 2010; Gregory, 2014]. The international feminist movement of the 1970s and 80s, plus the election of the Helen Clark Labour Government in 1989, led to increased numbers of women in leadership in New Zealand [Curtin, 2008]. The New Zealand Association for Women in the Sciences (AWIS) was started in early 1986, by a group of established scientists, including Dr Janet Bradford-Grieve, Dr Rosalind McIntosh and Dr Janet Davies [Davies, 2016]. The group was initially based in Wellington, but expanded rapidly to have branches in the main cities of New Zealand by the early 1990s. The Women's Suffrage Centennial Science Conference was organised by AWIS members in 1993 [Fleming, 1993]. The style of this gathering was totally different to the usual science conference: women talked openly about the feminist science issues, held workshops on juggling families with work, discussed feminist pedagogies and open access to data, and listened to Māori women talk about how they gathered data in their communities. Groups of delegates met in "talking circles" to discuss points the speakers had raised. For many, this was the first time they had heard people talking about art or poetry in science, or discussion of indigenous science [Cresswell, 1993].

The Zonta Club of Wellington established their Science Award and Medal for emerging women scientists in 1990 (http:/ / zontascience.org.nz). This award allowed the recipient to travel and establish new collaborations outside New Zealand. In a small publication produced by Zonta to celebrate the $10^{\text {th }}$ anniversary of the award, recipients confirmed the power of the award to increase their self-confidence, leadership and science communication skills [Sparrow, 2008]. 
2001-2010: outreach and engagement
Science centres: in 1991 Otago Museum opened Discovery World, the first science centre in New Zealand, followed soon after by Science Alive! in Christchurch in 1992. Funding from the New Zealand Lottery Grants Board and RSNZ, allowed science centres in Auckland (as part of the Museum of Transport and Technology), Palmerston North (Te Manawa), Wellington (Capital Discovery Place), Christchurch (Science Alive!) and Dunedin (Discovery World, as part of Otago Museum) to be established, followed a few years later by Hamilton (Exscite) [Hodder, 2010]. An increase of informal community discussions about science, in events such as café scientifique or "Science in the Pub" [Dallas, 2006; Lafrenière and Cox, 2012; Dallas, 2014; Grand, 2014], resulted in improved public engagement with scientific issues and promoted careers in science [Hodder, 2010].

The rise of science centres in New Zealand signalled the demise of old-style museums housing "collections" and ushered in museums that emphasised public engagement and hands-on experiences primarily for children, rather than research [Hodder, 2010]. These changes coincided with the launch of the International Science Festival in Dunedin in 1998. This has been a biannual event ever since [Fleming et al., 2017].

In the 1990s, the Museum of New Zealand Te Papa Tongarewa replaced the Dominion Museum in Wellington, under the Museum of New Zealand Te Papa Tongarewa Act 1992 [Attwood, 2013]. A mobile science centre, originating from Christchurch's Science Alive! science centre, took hands-on science outreach to smaller centres around the South Island of New Zealand [Hodder, 2010]. This mobile unit eventually became the National Science \& Technology Roadshow still operating today throughout New Zealand. Public outreach in New Zealand then developed rapidly.

National public radio: radio has been an important medium in the emergence of New Zealand science communication. A monthly Science Report radio programme was established briefly by the New Zealand Broadcasting service in 1957 [NZAS, 1958]. In 1999, Allan Coukell established the weekly Eureka! radio programme [Coukell, 2002]. Eureka! ran until 2005, with host Veronika Meduna from 2002. Regular science programming is now well established in the weekly Our Changing World, a programme of science narratives and interviews with scientists, on Radio New Zealand (RNZ) National [Our Changing World]. The late Professor Sir Paul Callaghan and RNZ National journalist Kim Hill did much to establish the place of science on Saturday morning radio, with their discussions on everything from the Big Bang and nanotechnology to novel cancer treatments [Callaghan and Hill, 2007]. Kim Hill and other RNZ hosts continue to welcome scientists of all persuasions to radio [Chapman, 2016; Crump, 2016; Hill, 2016].

The Royal Commission on Genetic Modification: another major event contributed to public engagement with science in New Zealand. In 2000 the new government of the New Zealand Labour Party, led by Prime Minister Helen Clark and with support from the New Zealand Greens, established the Royal Commission on Genetic Modification [Eichelbaum et al., 2001]. There followed 14 months of hot debate about the future of genetic modification (GM) in New Zealand. Over 10,000 personal written submissions were received, 92\% opposing any GM in New Zealand. Public meetings were held all over New Zealand and 
daily editorials or reports were published in all the main media. The RCGM demonstrated the inadequacy of the deficit model of science communication: commissioners concluded involvement of the public in the consideration of major ethical issues and in decision-making on such issues was of vital importance, when finding outcomes to today's problems [Fleming, 2003]. Much of the discussion was on the ethical, cultural and spiritual issues of GM, rather than on the science itself [Fleming, 2004]. An increase in levels of outreach and public engagement with science was seen all over New Zealand in subsequent years. In particular, the Labour Government established Toi te Taiao, The Bioethics Council, to encourage public discussion on controversial issues, including xenotransplantation, cloning, nanotechnology and genetic modification [Fleming, 2004; Toi te Taiao: The Bioethics Council, 2005; Toi te Taiao: The Bioethics Council, 2008]. However the incoming National Government disestablished Toi te Taiao on 11 March 2009 (http://www.mfe.govt.nz/website/closed-sites/bioethics.html).

Science for schools: New Zealand universities established secondary school science summer events as far back as 1989. The annual University of Otago's Hands-on Science programme celebrated 25 years of its "week of serious fun" in 2014 [Fleming et al., 2017]. The LENScience programme at the Liggins Institute, Auckland University [Bay et al., 2012] is the latest successful manifestation of such summer events. These programmes aim primarily to bring a larger diversity of students into science degrees. In 2007, in order to improve Māori participation in science, the University of Otago initiated a three-day, hands-on experience for secondary school students, in Māori communities throughout Aotearoa-New Zealand. The Science Wānanga encourage students to explore the connections between science, Mātauranga Māori and their lives, particularly in the areas of human health and environmental health [Fleming et al., 2017].

The first science fair, in which school students present the results of science projects to the public, was held in Auckland in 1959. The RSNZ has been involved in these national competitions since 1960 [Duncan and Suuring, 1979].

Art science collaborations: one of the country's longest-running art and science collaborations is the Artists to Antarctica programme. Painter Peter McIntyre travelled to Antarctica in 1957, and produced a series of landscape paintings [Feeney, 1996]. Artists have visited the ice annually, responding to the landscape, the science and the people, in paintings, poems, photographs, sculptures, novels and musical compositions. Today artists are now part of a wider Outreach and Engagement Programme [Antarctica New Zealand, 2017] helping people to understand the importance of research at the poles [Salmon et al., 2011; Betteley, Harr and Lee, 2013; Swanson, 2015].

In 2005, a project called Are Angel's OK teamed up leading New Zealand writers with physicists. Led by poet Bill Manhire and physicist Sir Paul Callaghan, the project resulted in a series of public performances, radio shows and a book [Callaghan and Manhire, 2006]. The collaborations inspired creative writing about dark energy, the curvature of space-time and wave particle duality. In an annual competition from 2007 to 2012, fiction and non-fiction writers contributed science-themed writings to the Royal Society of New Zealand Manhire Prize for Creative Science Writing [Manhire, 2012]. 
Other art-science collaborations included The Waking Incubator [Fleming et al., 2011], The Art of Nanotechnology

(http:/ / www.macdiarmid.ac.nz/tag/art-of-nanotechnology/) and a 2011 International Year of Chemistry celebration which resulted in a knitted periodic table now hanging in the School of Chemical and Physical Sciences at Victoria University of Wellington [Boniface, 2017].

The Science Communicators' Association of New Zealand
The New Zealand Science Media Centre
The Association of Scientific and Technical Communicators (NZ) Incorporated was started in 1987 [Jasperse, 1989]. It ran quarterly meetings with speakers, produced a newsletter, and in 1994 ran a successful 2-day Conference, 'Communicating Science, Communicating Technology' [Jasperse, 1994]. It continued until 1996, when it went into recess.

Agricultural journalist Peter Burke formally established The Science Communicators' Association of New Zealand (SCANZ) on 23 June 2004, with support from the Ministry of Research, Science \& Technology, signalling New Zealand's coming of age in science communication (http:/ / www.scanz.co.nz/about.html). As of 2016, SCANZ had over 100 members, most of whom work for science research, educational or policy institutions. Most members are journalists or public relations experts, with fewer and fewer scientists communicating science directly [Hendy, 2016].

While the country's public radio broadcaster offers regular high-quality science programming, New Zealand does not have a strong tradition of science journalism and lacks the depth of expertise in science journalism found in larger countries [Ashwell, 2014]. New Zealand's Science Media Centre was launched in 2008 as part of a Ministry of Research, Science and Technology strategy to "engage New Zealanders with science and technology". The establishment of the SMC acknowledged a worldwide trend towards having fewer dedicated science journalists [Ministry for Science, Research \& Technology, 2007], recognised barriers to science and technology reporting in New Zealand [Rusholme, 2008] and sought to overcome some of the limitations driven by the small scale of New Zealand's research organisations and media outlets [Ministry for Science, Research \& Technology, 2007].

Tertiary training specifically for science communicators started formally at Massey University in 1979, with a Communication option in the Diploma in Business and Administration, which included science communication [Sligo, 1990]. From 2000, following the merger between Massey University and the Wellington Polytechnic, the communication programmes were enhanced by the Polytechnic's long and successful record of teaching journalism [Sligo, 1990].

In 2001 NHNZ formed a partnership with the Zoology Department of the University of Otago in Dunedin, leading to the introduction of a Postgraduate Diploma in Natural History Filmmaking. The Centre for Science Communication at the University of Otago was established formally in 2008 by zoologist Lloyd Spencer Davis, in order to increase the number of graduates with communication 
skills in science and the ability to conduct research on effective science communication [Fleming, 2009].

At Victoria University of Wellington, an undergraduate paper in science communication was launched in 2014, seeking to give students a broader understanding of the role of science in society, the different publics and stakeholders, and the roles science communicators play [Victoria University of Wellington, 2016]. Unitec in Auckland runs a Bachelor of Applied Science (Science Communication), focused on giving students the skills to "present science information confidently to any audience" [Unitec, 2016].

The nation's top science communicators are celebrated with a number of medals and awards [Salmon and Priestley, 2015]. The Prime Minister's Prize for Science Media Communication awards $\$ 100,000$ to a "either a practising scientist who can demonstrate an interest, passion and aptitude for science communication and public engagement, or to a person who has developed expertise in public engagement with, or communication of complex scientific or technological information to the public" (http://www.pmscienceprizes.org.nz/media/). The RSNZ's prestigious Callaghan Medal is awarded to a person who has "made an outstanding contribution to science communication, in particular raising public awareness of the value of science to human progress"

(http://www.royalsociety.org.nz/programmes/awards/callaghan-medal/). These prizes are relatively new: being first offered in 2008 and 2011 respectively, but the New Zealand Association of Scientists' annual Science Communicator Award, given to a "practising scientist for excellence in communicating science to the general public", has been awarded since 1999 (http:/ / www.scientists.org.nz/awards/communicator-award).

New Zealand science writers were celebrated too, until recently. From 2007-2013 the RSNZ's Prize in Creative Science Writing was awarded to one fiction writer and one non-fiction writer, for their submissions on a topic set by the RSNZ each year. In 2009, the RSNZ launched a biennial prize for the country's best popular science book, "to encourage the writing, publishing and reading of good and accessible popular science books", but unfortunately this prize was discontinued in 2015 (see https:/ / rebeccapriestley.com/2017/02/22/does-new-zealand-need-a-sciencebook-prize/). Writers shortlisted for this prize have included scientists, science journalists, a science historian and a poet.

(http:/ / www.royalsociety.org.nz/programmes/competitions/science-bookprize/).

Increasing public engagement with science
It is pertinent to ask what underlies the long-term push from government and industry for better communication of science and technology. The push possibly arose in the wake of earlier government initiatives in the early 2000s for a knowledge-based, innovative economy, as well as proposals to develop a "Knowledge Society", with higher levels of public scientific literacy and more science, technology and engineering graduates [Casey, 2004]. However it may also signal governmental awareness of the rise in mistrust of science and scientists in the New Zealand community [Fleming, 2004; Lyver, 2005]. 
A series of surveys on New Zealanders' attitudes to science, from 2002 to 2010 [Hipkins et al., 2002; Hipkins, 2010], showed changes in public perceptions of science over this time, following concern about peak oil and climate change. The survey data also showed more and more New Zealanders saw science and technology as too specialised and that there was too much conflicting information about major scientific issues [Hipkins, 2010]. In March 2013, the National Science Challenges Panel, charged with responding to "the most important, national-scale issues and opportunities identified by science stakeholders and the New Zealand public" concluded that addressing 'deficits' in the public's 'appreciation and understanding of science' was 'of the highest priority' and suggested greater investment in the communication of science to the public as part of the remedy [Gluckman, 2013]. The New Zealand Government addressed this through a parallel Challenge, launched as the Science in Society Project, with the title "A Nation of Curious Minds" [New Zealand Government, 2014]. This Challenge aims to produce more science and technology competent learners, and more choosing science, technology, engineering and mathematics (STEM)-related career pathways, as well as a more scientifically and technologically engaged public and a more publicly engaged science sector.

However alongside this, there is increased market orientation of scientific organisations [Ashwell, 2014] and unease in the science community at politicians' ability to disregard or reject evidence-based research results. On an interview on the BBC's HARDtalk, in 2011, then New Zealand Prime Minister John Key was quizzed about the poor state of New Zealand's freshwaters and was challenged by data and statements from Freshwater Ecologist Dr Mike Joy, via the interviewer (http://news.bbc.co.uk/2/hi/programmes/hardtalk/9480610.stm). Key shrugged off the evidence and argued "he's one academic and, like lawyers, I can provide you with another one that can offer a counter view". The cynical might take the view that the push for better science communication has little to do with public engagement with science or indeed a knowledge-based economy and more to do with government control of scientists in this country.

The issue of freedom of communication has continued to concern New Zealand scientists, as reflected in the 2015 NZAS conference 'Going Public: Scientists Speaking Out on Difficult Issues' [Gaston, 2015] and Shaun Hendy's short book "Silencing Science" [Hendy, 2016]. In a recent publication, physicist Nicola Gaston wrote "the need to question ... science ... sits uncomfortably with the idea of science communication as a public relations exercise" and argued there was a role for the critiquing journalist in the dialogue between the scientist and the public [Gaston, 2016]. However, a recent study showed communicators and scientists believed science reporting by the New Zealand media was poor, especially in the case of commercial radio and television [Ashwell, 2014].

While science communication in New Zealand has grown significantly over the last twenty years, the current political climate makes free communication difficult [Gaston, 2016]. A more critical and strategic approach to science communication in New Zealand has been called for. In an article on the future of public engagement with New Zealand science, Salmon and Priestley [Salmon and Priestley, 2015] proposed a vision for the future of science communication in which "scientists, science communicators, and science policy are informed by theory, and 
theoreticians are informed by science communication practice", leading to engagement programmes that are more strategic, targeted and evaluated. There is a need to represent the diversity of New Zealand's science and scientists in public engagement. This would lead to both a more science-literate public, and a more public-literate science community, aligning well with the latest recommendations from international science engagement and communication literature [Smallman, 2016]. It would also create tangible steps towards a more democratic approach to science funding, research, and communication in New Zealand. The increase in opportunities for tertiary training in science communication signals a new era of reflection and research in New Zealand science communication.

Acknowledgments The authors wish to acknowledge the help and expertise of Rebecca Priestley (Victoria University of Wellington), Christine Ross and Peter Burke (SCANZ), Neil Harraway and Michael Stedman (NHNZ), Alan Petry, Fiona McDonald and Geoff Gregory (NZAS) and Daniel Hikuroa, Auckland University in the preparation of this manuscript.

References

Adds, P. (2012). 'Long-distance prehistoric two-way voyaging: the case for Aotearoa and Hawaiki'. Journal of the Royal Society of New Zealand 42 (2), pp. 99-103. DOI: 10.1080/03036758.2012.677456.

Ahteensuu, M. (2011). 'Assumptions of the Deficit Model Type of Thinking: Ignorance, Attitudes, and Science Communication in the Debate on Genetic Engineering in Agriculture'. Journal of Agricultural and Environmental Ethics 25 (3), pp. 295-313. DOI: 10.1007/s10806-011-9311-9.

Anon. (1919). 'The Science Congress, Christchurch, New Zealand'. Journal of the Polynesian Society 28 (109), pp. 52-53.

- (1921). 'Second Congress, Palmerston North, 25-29 January 1921'. NZ Journal of Agriculture 22 (2), pp. 108-109.

Antarctica New Zealand (2017). Community Engagement Programme. URL: http://ww w. antarcticanz.govt.nz/education/communityengagementprogramme/ (visited on 3rd March 2017).

Ashwell, D. J. (2014). 'The challenges of science journalism: The perspectives of scientists, science communication advisors and journalists from New Zealand'. Public Understanding of Science 25 (3), pp. 379-393. DOI: $10.1177 / 0963662514556144$.

Atkinson, J. D. (1976). 'DSIR's first fifty years'. In: Department of Scientific and Industrial Research Information Series. Wellington, Australia: Department of Scientific and Industrial Research. DOI: 10.7931/DL1-DIS-115.

Attwood, B. (2013). 'Difficult Histories: The Museum of New Zealand Te Papa Tongarewa and the Treaty of Waitangi Exhibit'. The Public Historian 35 (3), pp. 46-71. DOI: 10.1525/tph. 2013.35.3.46.

Baker, M. (2010). 'Career confidence and gendered expectations of academic promotion'. Journal of Sociology 46 (3), pp. 317-334. DOI: $10.1177 / 1440783310371402$.

Ballance, A. Our Changing World. Radio New Zealand. URL: http://www.radionz.co.nz/national/programmes/ourchangingworld (visited on 30th October 2016). 
Bay, J. L., Dewan, C., Cole, K., Pamaka, S., Wagner, B. and Mora, H. (2012). Effective School-science Partnerships: The LENScience Story. Auckland, New Zealand: The Liggins Institute.

Best, E. (1930). 'Māori Agriculture. Cultivated food-plants of the Maori and native methods of agriculture'. Journal of the Polynesian Society 39 (4), pp. 346-380.

- (1931). 'Māori Agriculture. Cultivated food-plants of the Maori and native methods of agriculture'. Journal of the Polynesian Society 40 (1), pp. 1-22.

Betteley, P., Harr, N. and Lee, R. E. (2013). 'Sharing Antarctic Research in the Classroom: Authentic Outreach as a Means of Improving Student Performance'. Performance Improvement 52 (1), pp. 16-23. DOI: 10.1002/pfi.21317.

Beveridge, A. E., Christensen, B. R., Smale, M. C. and Bergin, D. O. (2009). Ecology, management and history of the forests of the Mamaku Plateau, New Zealand. Wellington, New Zealand: Department of Conservation.

Boniface, S. (2017). Knitting the Periodic Table (IYC Project). URL: http://nzscienceteacher.co.nz/standing-committees/chemistry-nzi c/periodic-table-more-changes/\#. WVbfl4pLdBw (visited on 1st July 2017).

Brooking, T. (2004). The History of New Zealand. Greenwood Publishing Group.

Brooks, A. (1997). Academic women. Buckingham, U.K.: Society for Research into Higher Education and Open University Press.

Broughton, D. and McBreen, K. (2015). 'Mātauranga Māori, tino rangatiratanga and the future of New Zealand science'. Journal of the Royal Society of New Zealand 45 (2), pp. 83-88. DOI: 10.1080/03036758.2015.1011171.

Callaghan, F. R. (1976). 'History and role of scientific periodicals in New Zealand'. NZ Journal of Science 19 (1), pp. 3-9.

Callaghan, P. and Hill, K. (2007). As Far as We Know: Conversations About Science, Life and the Universe. New Zealand: Penguin Books.

Callaghan, P. and Manhire, B. (2006). Are Angels OK? The parallel universes of New Zealand writers and scientists. Wellington, New Zealand: Victoria University Press.

Casey, C. (2004). 'Knowledge-Based Economies, Organizations and the Sociocultural Regulation of Work'. Economic and Industrial Democracy 25 (4), pp. 607-627. DOI: $10.1177 / 0143831 \times 04047161$.

Chapman, W. (2016). Sunday Morning. Radio New Zealand. URL: http://www.radionz.co.nz/national/programmes/sunday (visited on 30th October 2016).

Coukell, A. (2002). Eureka!

URL: https://thirdcoastfestival .org/explore/person/allan-coukell (visited on 30th October 2016).

Crawford, S. (2009). 'Mātauranga Māori and western science: The importance of hypotheses, predictions and protocols'. Journal of the Royal Society of New Zealand 39 (4), pp. 163-166. DOI: 10.1080/03014220909510571.

Cresswell, M., ed. (1993). Celebrating women in science: proceedings of the Women's Suffrage Centennial Science Conference. Wellington, New Zealand: AWIS.

Crump, B. (2016). Nights. Radio New Zealand.

URL: http://www.radionz.co.nz/national/programmes/nights (visited on 22nd June 2017).

Curtin, J. (2008). 'Women, Political Leadership and Substantive Representation: the Case of New Zealand'. Parliamentary Affairs 61 (3), pp. 490-504.

DOI: $10.1093 / \mathrm{pa} / \mathrm{gsn} 014$. 
Dallas, D. (2006). 'Café Scientifique — Déjà Vu'. Cell 126 (2), pp. 227-229. DOI: $10.1016 / \mathrm{j}$. cell.2006.07.006.

- (2014). 'Café Scientifique'. In: Communicating Science to the Public. Ed. by L. Tan Wee Hin and R. Subramaniam. Singapore, pp. 261-275. DOI: $10.1007 / 978-94-017-9097-0 \_16$.

Davies, J. (2016). How AWIS started. NZ Association for Women in the Sciences. URL: http://www . awis .org.nz/about-us/how-awis-started/ (visited on 11th August 2016).

Dewes, K. (2012). 'Peace and Disarmament Activism'. In: Public Participation in Foreign Policy, pp. 105-133. DOI: 10.1057/9780230367180_5.

Donald, S. L. (2012). 'Dual heritage, shared future: James Cook, Tupaea and the transit of Venus at Tolaga Bay'. Journal of the Royal Society of New Zealand 42 (2), pp. 79-85. DOI: 10.1080/03036758.2012.672431.

Downes, D. (2000). 'The New Zealand Environmental Movement and the Politics of Inclusion'. Australian Journal of Political Science 35 (3), pp. 471-491. DOI: $10.1080 / 713649347$.

Duncan, J. F. and Suuring, D. (1979). A History of New Zealand Science Fairs. Report 21. Victoria University of Wellington, Chemistry Department.

Eichelbaum, T., Allan, J., Fleming, J. and Randerson, R. (2001). Report of the Royal Commission on Genetic Modification. Wellington, New Zealand: Department of Internal Affairs. URL: http://www.mfe.govt.nz/publications/hazards/repor t-royal-commission-genetic-modification.

Feeney, W. (1996). 'The war paintings of Peter McIntyreArt New Zealand'. 77 (Summer 1995-96). Sourced in Te Ara: The Encyclopedia of New Zealand, pp. 70-73. URL: http: //teara. govt.nz (visited on 1st July 2017).

Fleming, C. A. (1987). Science, Settlers and Scholars. Wellington, New Zealand: The Royal Society of New Zealand.

Fleming, J. S. (1993). 'Foreword'. In: Celebrating women in science: proceedings of the Women's Suffrage Centennial Science Conference. Ed. by M. Cresswell. Wellington, New Zealand: AWIS.

- (2003). 'Inform, educate or influence? New Zealand's experience of the debate on genetic modification'. The Round Table 92 (371), pp. 487-499. DOI: $10.1080 / 0035853032000126174$.

- (2004). 'Ethical, cultural and spiritual objections to genetically modified organisms: a review of the New Zealand process and perspective'. eng. Alternatives to laboratory animals: ATLA 32 (Suppl. 1), pp. 21-27. PMID: 23577431.

- (2009). 'Talking with barmaids: the importance of science communication in today's changing world'. International Journal of Science $\mathcal{E}$ Society 1 (1).

Fleming, J. S., Gibson, R., Harris, B., Morgan, S., Noble, A., O'Keeffe, K., Wirz-Justice, A., Trubridge, S. and Gander, P. (2011). "The "Waking Incubator": exploring the interface between the performing arts and the science of sleep'. International Journal of Science \& Society 2 (3), pp. 291-308.

Fleming, J. S., Broni, B., Copeland, S., Hunt, D. and Newburn, R. (2017). 'Thirty years of science outreach at the University of Otago'. New Zealand Science Review 74 (1), pp. 10-13.

Gaston, N. (2015). 'Empowering informed voices. NZAS Annual Conference: keynote address'. New Zealand Science Review 72 (1), pp. 3-6.

Gaston, N. (2016). 'Scientific fact: Neither sacred nor free'. In: Don't Dream it's Over: Reimagining Journalism in Aotearoa New Zealand. Ed. by E. Johnson, G. Tiso, S. Illingworth and B. Bennett. Christchurch, New Zealand: Freerange Press. 
Gill, B. J. (2006). 'Birds in Australian and New Zealand museums - a major resource for ornithology'. New Zealand Journal of Zoology 33 (4), pp. 299-315. DOI: $10.1080 / 03014223.2006 .9518458$.

- (2010). 'The Cheeseman-Giglioli correspondence, and museum exchanges between Auckland and Florence, 1877-1904'. Archives of Natural History 37 (1), pp. 131-149. DOI: 10.3366/e0260954109001697.

Gluckman, P. (2013). Report of the National Science Challenges Panel. Ed. by Ministry of Science and Innovation. Wellington, New Zealand: NZ Government.

Grand, A. (2014). 'Café Scientifique'. Science Progress 97 (3), pp. 275-278. DOI: $10.3184 / 003685014$ X14098305289149.

Gregory, G. (2013). 'Not to be forgotten: New Zealand Association of Scientific Workers'. New Zealand Science Review 70 (1), pp. 10-19.

- (2014). 'Tackling issues and initiating public debate: New Zealand Association of Scientists 1974-91'. New Zealand Science Review 71 (4).

Hayward, M. (2014). 'The influence of party leaders on women's representation in parliament, 1935-1975: the case of New Zealand'. Commonwealth \& Comparative Politics 52 (2), pp. 254-270. DOI: 10.1080/14662043.2014.894279.

Hector, J. (1891). Report of the Third Meeting of the Australasian Association for the Advancement of Science. 1891 Christchurch, New Zealand. Sydney, Australia: ANZAAS.

Hendy, S. (2016). Silencing Science: Science that is not heard is not science at all. Bridget Williams Books. DOI: 10.7810/9780947492847_1.

Henwood, W. (2007). 'Māori knowledge: a key ingredient in nutrition and physical exercise health promotion programmes for Maori'. Social Policy Journal of New Zealand 32, pp. 155-164.

Heron, E. L. (2004). ‘Placing Geographical Imagination in Film: New Zealand Filmmakers' Use of Landscape'. New Zealand Geographer 60 (1), pp. 60-66. DOI: $10.1111 / j .1745-7939.2004 . t b 01706 . x$.

Higham, T., Anderson, A. and Jacomb, C. (1999). 'Dating the first New Zealanders: the chronology of Wairau Bar'. Antiquity 73 (280), pp. 420-427. DOI: $10.1017 / \mathrm{s} 0003598 \times 00088360$.

Hill, K. (2016). Saturday Morning. Radio New Zealand. URL: http://www.radionz.co.nz/national/programmes/saturday (visited on 30th October 2016).

Hipkins, R. (2010). 'Public attitudes to science: Rethinking outreach initiatives'. New Zealand Science Review 67 (4), pp. 114-121.

Hipkins, R., Stockwell, W., Bolstad, R. and R., B. (2002). Commonsense, trust and science: How patterns of beliefs and attitudes to science pose challenges for effective communication. Ed. by Ministry of Research, S. T. Wellington, New Zealand: New Zealand Government.

Hirini, P. (2006). ‘New Zealand Māori thought and modern psychology: Te matai hinengato me te mātauranga Māori'. Australian Journal of Psychology 58, pp. 145-145.

Hodder, P. (2010). 'Out of the laboratory and into the knowledge economy: A context for the evolution of New Zealand science centres'. Public Understanding of Science 19 (3), pp. 335-354. DOI: 10.1177/0963662509335526.

Jasperse, J. A. (1989). Executive Secretary's report on the first 2 years of Association activities. Wellington, New Zealand: New Zealand Association of Science Communicators. 
Jasperse, J. A. (1994). 'Communicating Science, Communicating Technology'. In: Proceedings of the First Conference of the Association of Scientific and Technical Communicators (New Zealand). Wordstream Corporation Ltd.

Jenkins, K. and Pihama, L. (2001). ‘Mātauranga Wahine: Teaching Māori Women's Knowledge Alongside Feminism'. Feminism \& Psychology 11 (3), pp. 293-303. DOI: $10.1177 / 0959353501011003003$.

Lafrenière, D. and Cox, S. M. (2012). 'Means of Knowledge Dissemination: Are the Café Scientifique and the Artistic Performance Equally Effective?' Sociology Mind 02 (02), pp. 191-199. DOI: 10.4236/sm. 2012.22025.

Lyver, P. O. B. (2005). 'Co-managing environmental research: lessons from two cross-cultural research partnerships in New Zealand'. Environmental Conservation 32 (04), p. 365. DOI: 10.1017/s0376892905002535.

Lyver, P. O. B., Taputu, T. M., Kutia, S. T. and Tahi, B. (2008). ‘Tuhoe Tuawhenua mātauranga of kereru (Hemiphaga novaseelandiae novaseelandiae) in Te Urewera'. New Zealand Journal of Ecology 32 (1), pp. 7-17.

Manhire, B. (2012). Manhire Prize for Creative Science Writing. Royal Society of New Zealand. URL: http://www.royalsociety.org.nz/programmes/competitions /manhire-prize/ (visited on 30th October 2016).

Mark, A. (2001). 'Integrating conservation with hydro-electric development of Lakes Manapouri and Te Anau, New Zealand: an exercise in complexity'. Complexity International 8 (1), pp. 1-19.

Mark, A. F. and Johnson, P. N. (1985). 'Ecologically derived guidelines for managing two New Zealand lakes'. Environmental Management 9 (4), pp. 355-363. DOI: 10.1007/bf01867306.

McCarthy, T. P. (1978). Nuclear Power Generation in New Zealand: Report of the Royal Commission of Inquiry presented to the House of Representatives. Wellington, New Zealand: Government Print.

McNeil, M. (2013). 'Between a Rock and a Hard Place: The Deficit Model, the Diffusion Model and Publics in STS'. Science as Culture 22 (4), pp. 589-608. DOI: $10.1080 / 14636778.2013 .764068$.

Mead, S. M. (1983). 'Te toi mātaurangaa Māori mo nga ra kei mua mua - Māori studies tomorrow'. Journal of the Polynesian Society 92 (3), pp. 333-351.

Ministry for Science, Research \& Technology (2007). Request for proposal to develop and operate a Science \& Technology Media Centre. Wellington, New Zealand: New Zealand Government.

URL: http://www.sciencemediacentre.co.nz/about/.

Moller, H. (2009). 'Mātauranga Māori, science and seabirds in New Zealand'. Neww Zealand Journal of Zoology 36 (3), pp. 203-210. DOI: 10.1080/03014220909510151.

Moller, H., O’Blyver, P., Bragg, C., Newman, J., Clucas, R., Fletcher, D., Kitson, J., McKechnie, S., Scott, D. and Administering, R. T. I. (2009). 'Guidelines for cross-cultural Participatory Action Research partnerships: A case study of a customary seabird harvest in New Zealand'. New Zealand Journal of Zoology 36 (3), pp. 211-241. DOI: 10.1080/03014220909510152.

Murray, A. and Howse, D. (1997). 'Lieutenant Cook and the transit of Venus, 1769'. Astronomy \& Geophysics 38 (4), pp. 27-30. DOI: 10.1093/astrog/38.4.27.

Nelson, W., Dalen, J. and Neill, K. (2013). 'Insights from natural history collections: analysing the New Zealand macroalgal flora using herbarium data'. PhytoKeys 30, pp. 1-21. DOI: $10.3897 /$ phytokeys.30.5889.

New Zealand Government (2014). A Nation of Curious Minds - He Whenua Hihiri i te Mahara. A National Strategic Plan for Science in Society. Wellington, New Zealand: Ministry of Business, Innovation and Employment. 
NZAS (1958). ‘Council notes: Publicity of science'. New Zealand Science Review 16 (3-4), p. 52.

Perry, G. L. W., Wilmshurst, J. M. and McGlone, M. S. (2014). ‘Ecology and long-term history of fire in New Zealand'. New Zealand Journal of Ecology 38 (2), pp. 157-176.

Priestley, R. (2006). ‘Ernest Marsden's Nuclear New Zealand: From Nuclear Reactors to Nuclear Disarmament'. Journal and Proceedings of the Royal Society of New South Wales 139, pp. 23-38.

Priestley, R. (2010). 'A Survey of the History of Science in New Zealand 1769-1992'. History Compass 8 (6), pp. 474-490. DOI: 10.1111/j .1478-0542.2010.00684.x.

Reitzig, A. (2005). 'New Zealand's ban on nuclear-propelled ships revisited'. Master of Arts. The University of Auckland, New Zealand.

Roberts, M. (1991). 'Origin, dispersal routes, and geographic distribution of Rattus exulans, with special reference to New Zealand'. Pacific Science 45 (2), pp. 123-130.

Robinson, T. Z. (2012). “'On the influence of the scientific societies of New Zealand on the character of the nation": Collecting and identity at the Hawke's Bay Philosophical Institute museum, 1874-1899'. Journal of the History of Collections 25 (1), pp. 87-102. DOI: 10.1093/jhc/fhr030.

Rusholme, S. (2008). Proposal for the New Zealand Science \& Technology Media Centre. Wellington, New Zealand: Royal Society of New Zealand.

Salmon, R. A. and Priestley, R. K. (2015). 'A future for public engagement with science in New Zealand'. Journal of the Royal Society of New Zealand 45 (2), pp. 101-107. DOI: 10.1080/03036758.2015.1023320.

Salmon, R. A., Carlson, D. J., Zicus, S., Pauls, M., Baeseman, J., Sparrow, E. B., Edwards, K., Almeida, M. H., Huffman, L. T., Kolset, T., Malherbe, R. J. H., McCaffrey, M. S., Munro, N. A. L., de Pomereu, J., Provencher, J., Rahman-Sinclair, K. A. and Raymond, M. (2011). 'Education, outreach and communication during the International Polar Year 2007-2008: stimulating a global polar community'. The Polar Journal 1 (2), pp. 265-285. DOI: $10.1080 / 2154896 \mathrm{x} .2011 .626629$.

Sligo, F. E. (1990). Business Communication: New Zealand Perspectives. Palmerston North, New Zealand: Software Technology Ltd.

Smallman, M. (2016). 'Public Understanding of Sciencein turbulent times III: Deficit to dialogue, champions to critics'. Public Understanding of Science 25 (2), pp. 186-197. DOI: 10.1177/0963662514549141.

Sparrow, M. (2008). Making a difference: The Zonta Science Awards 10th Anniversary Commemorative Booklet. Wellington, New Zealand: Zonta International.

Star, J. (2015). 'Real-life science communicators: learning from the experiences of television production company NHNZ'. Master of Science Communication. University of Otago, New Zealand. URL: http://hdl . handle .net/10523/5870.

Swanson, F. J. (2015). 'Confluence of arts, humanities, and science at sites of long-term ecological inquiry'. Ecosphere 6 (8), pp. 1-23. DOI: $10.1890 /$ es15-00139.1.

Toi te Taiao: The Bioethics Council (2005). The Cultural, Ethical and Spiritual Aspects of Animal-to-Human Transplantation. Wellington, New Zealand: Ascentum.

— (2008). Who gets born? Pre-birth testing. Wellington, New Zealand: Ascentum. 
Unitec (2016). Bachelor of Applied Science (Science Communication). Auckland.

URL: http://www . unitec.ac.nz/career-and-study-options/animal-healthand-welfare/bachelor-of-applied-science-science-communication (visited on 30th October 2016).

Victoria University of Wellington (2016). SCIE311 Science Communication. URL: http://www.victoria.ac.nz/courses/scie/311/2016 (visited on 30th October 2016).

Vowles, J. (1995). 'The politics of electoral reform in New Zealand'. International Political Science Review 16 (1), pp. 95-115.

Wilmshurstl, J. M. and Higham, T. F. G. (2004). 'Using rat-gnawed seeds to independently date the arrival of Pacific rats and humans in New Zealand'. The Holocene 14 (6), pp. 801-806. DOI: 10.1191/0959683604hl760ft.

Wright, L. W. (1980). 'Decision making and the logging industry: An example from New Zealand'. Biological Conservation 18 (2), pp. 101-115.

DOI: 10.1016/0006-3207 (80)90075-0.

Authors

\section{How to cite} Companion of the Royal Society of New Zealand in 2011.

E-mail: jean.fleming@otago.ac.nz. the history of natural history filmmaking in New Zealand.

E-mail: jeremy.star@gmail.com. Aotearoa New Zealand'. JCOM 16 (03), A02. Otago, in the Centre for Science Communication in Dunedin, New Zealand. Jean has a $\mathrm{PhD}$ in reproductive biology and worked for over 20 years in the health sciences at Otago, with research interests in the molecular and cellular origins of ovarian cancer. From 2000-2001 she was a Commissioner on the New Zealand Royal Commission on Genetic Modification. Jean's work with women in science and public engagement with science have earned nationwide accolades, including a Suffrage Medal in 1993, a Royal Society of New Zealand Silver Science and Technology Medal in 1998, an ONZM for services to science in 2002 and the NZ Association of Scientists' Science Communication Medal in 2016. She was made a

Jeremy Star is a freelance video editor in Auckland, New Zealand. He has editorial experience with Warner Bros International, SKY TV New Zealand, Greenstone TV, Notable Pictures and Imagination Television. In 2014, the University of Otago awarded him a distinction for his Masters degree in Science Communication in Natural History Filmmaking. Jeremy's thesis, "Real-Life Science Communicators: learning from the experiences of television production company NHNZ", covered

Fleming, J. and Star, J. (2017). ‘The emergence of science communication in 